\title{
Evaluation of a hydrocyclone system and ceramic membrane for oily water
}

\section{treatment purposes}

\author{
Avaliação de um sistema hidrociclone e membrana cerâmica para fins de tratamento de águas \\ oleosas \\ Evaluación de un sistema de hidrociclón and cerámica mebrana para el tratamiento de aguas \\ aceitosas
}

Received: 11/15/2021 | Reviewed: 11/23/2021 | Accept: 11/26/2021| Published: 12/09/2021

\author{
Kepler Borges França \\ ORCID: https://orcid.org/ 0000-0001-5456-2066 \\ Universidade Federal de Campina Grande, Brasil \\ E-mail: kepler123@gmail.com \\ Adriana Barbosa da Costa Pereira \\ ORCID: https://orcid.org/0000-0002-1082-7066 \\ Universidade Federal de Campina Grande, Brasil \\ E-mail: dribarbosaabc@gmail.com \\ Cristiane Rodrigues Macêdo \\ ORCID: https://orcid.org/0000-0002-8846-1076 \\ Universidade Federal de Campina Grande, Brasil \\ E-mail: cris.rmacedo@gmail.com \\ Carolina Pereira Dantas \\ ORCID: https://orcid.org/0000-0002-7921-0179 \\ Universidade Federal de Campina Grande, Brasil \\ E-mail: carolinapdantas@yahoo.com.br \\ Karine Oliveira da Costa \\ ORCID: https://orcid.org/0000-0002-9185-8226 \\ Universidade Federal de Campina Grande, Brasil \\ E-mail: karineocosta27@gmail.com
}

\begin{abstract}
The management of produced water is a huge challenge for oil companies, as environmental agencies use increasingly strict laws and require a primary treatment for the disposal of waste. The conventional methods used in the treatment of oily water, cannot satisfactorily remove the environmental laws. A system is presented, with a hydrocyclone built within LABDES/UFCG, tested and characterized with oily waters with different levels of oil concentrations, in order to study its efficiency. It was observed that for different oil concentrations in the hydrocyclone feed stream of (100 to 2000) $\mathrm{mg} \mathrm{L-1}$, total oil and grease, reached an efficiency above $85 \%$. The set of ceramic membranes, MR01-10 and MR02-20, with porosities of $43 \%$ and $52 \%$, were used in the assembly of two types of systems, SMC-DE and SMCFC. SMC-FC showed a removal rate above $80 \%$ for an average production of $165 \mathrm{~L} \mathrm{~h}-1 \mathrm{~m}-2$. However, SMC-DE proved to be more efficient in relation to TOG, above $98 \%$, but less efficient in relation to the permeate production flow, $63.3 \mathrm{~L}$ h-1.m-2. The hydrocyclone system with cross-flow ceramic membrane (SH-MC/FC) was chosen to study the reduction of oil in oily water, for a concentration range of (200 to 2000) $\mathrm{mg} \mathrm{L}-1$, which presented a removal rate above $95 \%$.
\end{abstract}

Keywords: Oily waters; Treatment; Hydrocyclone-membrane system.

\section{Resumo}

O gerenciamento de águas produzidas constitui-se em um enorme desafio para as empresas petrolíferas, visto que os órgãos ambientais usam leis cada vez mais severas e que exigem um tratamento primário ao descarte dos rejeitos. Os métodos convencionais utilizados no tratamento de águas oleosas, não conseguem remover a contento das leis ambientais. Um sistema é apresentado, com hidrociclone construído no âmbito do LABDES/UFCG, testado e caracterizado com águas oleosas com diferentes níveis de concentrações de óleo, com o intuído de estudar sua eficiência. Foi observado que a redução de óleo para uma faixa de concentração na corrente de alimentação do hidrociclone de (100 a 2000) mg L-1, a taxa de óleo e graxas (TOG), chegou a uma eficiência acima de $85 \%$. O conjunto de membranas cerâmicas, MR01-10 e MR02-20, com porosidades de $43 \%$ e $52 \%$ foram utilizadas na montagem de dois tipos de sistemas, SMC-DE e SMC-FC. O SMC-FC apresentou uma taxa de remoção acima de $80 \%$ para uma produção média de 165 L h-1 m-2. Todavia, o SMC-DE se mostrou mais eficiente em relação ao TOG, acima de $98 \%$, porém menos eficiente em relação ao fluxo de produção de permeado, $63,3 \mathrm{~L} \mathrm{h-1} \mathrm{m-2.} \mathrm{O} \mathrm{sistema}$ 
hidrociclone com membrana cerâmica de fluxo cruzado (SH-MC/FC), foi o escolhido para estudar a redução de óleo em águas oleosas, para uma faixa de concentração de (200 a 2000) mg L-1, a qual apresentou uma taxa de remoção acima de $95 \%$.

Palavras-chave: Águas oleosas; Tratamento; Sistema hidrociclone-membrana.

\section{Resumen}

La gestión del agua producida es un gran desafío para las empresas petroleras, ya que las agencias ambientales utilizan leyes cada vez más estrictas y requieren un tratamiento primario para la eliminación de residuos. Los métodos convencionales utilizados en el tratamiento de agua aceitosa no pueden eliminar satisfactoriamente las leyes ambientales. Se presenta un sistema, con un hidrociclón construido dentro del alcance de LABDES / UFCG, ensayado y caracterizado con aguas aceitosas con diferentes niveles de concentración de aceite, con el fin de estudiar su eficiencia. Se observó que la reducción de aceite para un rango de concentración en la corriente de alimentación del hidrociclón de (100 a 2000) mg L-1, la relación de aceite y grasa (TOG), alcanzó una eficiencia superior al 85\%. El conjunto de membranas cerámicas MR01-10 y MR02-20, con porosidades del 43\% y 52\%, se utilizó en el montaje de dos tipos de sistemas, SMC-DE y SMC-FC. El SMC-FC mostró una tasa de remoción superior al $80 \%$ para una producción promedio de $165 \mathrm{~L}$ h-1 m-2. Sin embargo, SMC-DE demostró ser más eficiente en relación a TOG, por encima del 98\%, pero menos eficiente en relación al flujo de producción de permeado, 63,3 L h-1 m-2. Se eligió el sistema de hidrociclón con membrana cerámica de flujo cruzado (SH-MC / FC) para estudiar la reducción de aceite en agua aceitosa, para un rango de concentración de (200 a 2000) mg L-1, que presentó una tasa de remoción arriba $95 \%$. Palabras clave: Agua aceitosa; Tratamiento; Sistema de membrana de hidrociclón.

\section{Introduction}

In the oil production process, water is considered one of the most undesirable contaminants, which is produced in large volumes and its presence causes a series of problems in the production stages. Emulsions are formed during the passage of oil and water from the reservoir to the surface and have greater or lesser stability, mainly as a function of the flow regime and the presence of emulsifying agents that prevent the coalescence of water droplets. It is necessary, then, to treat this water in order to recover part of the emulsified oil and condition it for reinjection or for disposal (Thomas et al., 2001).

The Revista Ciencia Hoje (2003) highlighted the difficulty of separating water associated with oil especially when emulsions are furned. There are risks caused by corrosion and obstruction of the pores of the reservoir that this mixture causes, which can account for up to $70 \%$ of the expenses of an oil company. Revista Ciencia Hoje (2003) highlighted the difficulty of separating water associated with oil, especially the formed emulsions. There are risks caused by corrosion and obstruction of the reservoir pores that this mixture causes, which can account for up to $70 \%$ of an oil company's expenses (Sousa Filho, 2002).

Environmental regulatory institutions are increasingly demanding whiten regarding the classification of oily water generated in various industrial activities. Thus, the adaptation of the activities of the oil production industries to the standards of effluent discharge is increasingly rigorous (article 24 of CONAMA 357). In addition, the treatment must be free from inconveniences arising from odors and noise and without causing negative environmental impact (Damasceno, 2009)

Thomas et al. (2001) reports the current oil/water separation process being done through a series of steps. Hydrocyclones and flotation are the most used separation processes. The emulsion destabilization step is carried out by thermochemical, electrical and chemical treatment. The water produced in onshore wells, after treatment, may present oil contents around $5 \mathrm{mg} \mathrm{L}-1$. In marine systems, values are around $30 \mathrm{mg} \mathrm{L}-1$. The oil/water separation process with membranes offers a new option for the engineer to face these challenges.

Ceramic membranes have been used in the chemical and petrochemical, pharmaceutical, metallurgical, environmental, food and electronics industries due to their substantial chemical, thermal and mechanical stability compared to organic membranes. Recently, due to a drop in prices, these membranes were adopted for the treatment of groundwater, with superior performance compared to conventional treatment (Bottino et al., 2001; Matsushita et al., 2005; Cui et al., 2011) investigated the use of a ceramic membrane in the seawater pre-treatment process for desalination processes and concluded 
that the quality of the permeate produced by the ceramic membrane is adequate to be fed to a seawater desalination process sea by reverse osmosis.

Some of the treatments for oily waters are inefficient, which are often reused or improperly discarded in nature, outside the required standards. As a result, many studies have been developed to improve this process of treating these oily waters. Cyclones are among the most used equipment for particulate separation. It has been patented by John M. Finch in the United States, only for water sand removal use. They have been widely used in various industrial processes, such as physical process separation and chemical reactions (Hoffmann \& Stein, 2008; Salvo, 2009).

Among the main advantages of using the hydrocyclone for solid/liquid, liquid/liquid separation include the fact that they are simple, cheap, easy to install, occupy a small area, low maintenance cost and low operating cost (Arruda, 2008, Castilho \& Medronho, 2000).

Aiming to contribute to the studies of produced water treatment, this work used a system hydrocyclone and ceramic membrane system to remove oil from water in the drilling of oil wells, in their various concentrations obtained in the drilling, leaving them within the standards required by regulatory institutions. The effluent chosen for the studies and laboratory tests comes from the drilling of oil wells at Fazenda Belém in the city of Mossoró - RN. A hydrocyclone will be built based on data from the dissertation of Souza (2009).

The tests were carried out on laboratory scale and, based on the variation of oil concentration in water, aiming to find an adequate pressure range that inpuced the optimal efficiency for oil removal in the ceramic membrane system and the hydrocyclone's efficiency and operation analysis. From these results, a system was set up using the hydrocyclone as a pretreatment of these oily waters, followed by a ceramic membrane in series for better efficiency in oil removal.

\section{Methodology}

The activities developed in this work were carried out at the Reference Laboratory for Desalination (LABDES, UFCG - PB) in conjunction with the Ceramic Membranes Laboratory (LABCEM, UFCG - PB), in which research projects in the treatment of oily water have been developed from ceramic membranes, aiming at its reuse as well as its proper disposal in compliance with CONAMA (2008) standards.

The treatment of oily water was carried out utilizing a hydrocyclone and a set of ceramic membranes. As evaluation parameters in this research, the TOG and the operation flow of each step of the system were analyzed, composing a database, in order to provide enough information to define a better oily water treatment system.

Oil/water mixtures were prepared (Figure 1) the oil was weighed using a precision scale, and then its mass divided into ten portions for the preparation of the oil/water solution so that: each portion was mixed with $24 \mathrm{~L}$ of desalinated water, with the aid of an Ultra Turrax - IKA T18 Basic type stirrer, for half an hour and then placed in the system's feed tank, totaling 250L.A nonionic surfactant liquid called Renex (nonylphene-ethoxylated 9.5 OE) was used, three drops for every 20ParaL of solution, as a way to minimize oil adhesion on the contact surfaces.

Despite the execution of this step, an adherence was observed with the mixing time, a decrease in the oil concentration in the studied oily water solutions. Given the above, it became necessary to redo the analysis (TOG's) of the solutions used to know the absolute concentrations.

To determine the TOG (total oil and grease) of the membrane permeate, the method described by Queirós et al. (2004) was used, as a quantitative method. Initially, it is necessary to construct a calibration curve for concentrations, established in mg L-1 of oil in water, as a function of absorbance read in the Biochrom Libra S60 spectrophotometer. 
Figure 1. Sample preparation steps for reading in the spectrophotometer (A) Transfer of the oil sample to the funnel; (B) Start of the oil extraction process; (C) Indication of the end of the extraction by the whitish coloration in the phases.

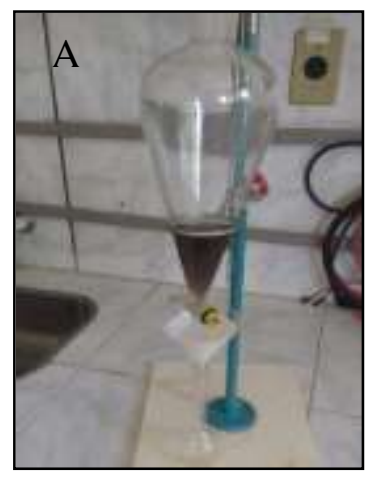

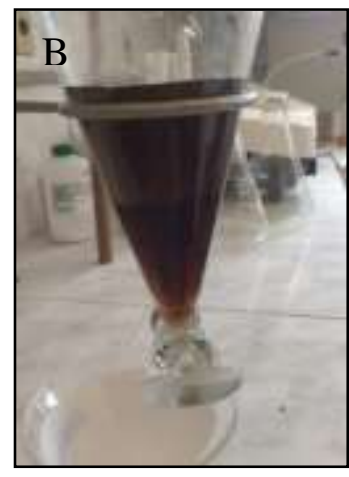

Source: Authors.

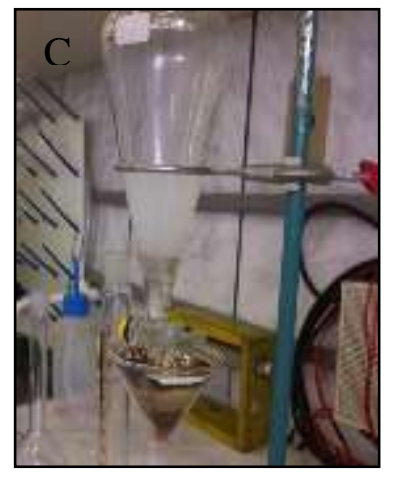

A preparation of the collected samples was carried out to read them in the spectrophotometer. To this end, chloroform was added in a separating funnel containing $50 \mathrm{ml}$ of oily water, and by manual and careful agitation of the separating funnel it was possible to obtain two phases of the mixture (B), with the removal of the lower phase, ie, chloroform + oil, performed through the balloon valve.

The addition of chloroform and separation were carried out as often as necessary, until the upper phase remained whitish and the lower one was transparent, as shown in Figure 2(C). With the final volume of water remaining in the separating funnel measured in a beaker, the flask that received the oil and chloroform solution separated from the funnel was completed with chloroform until reaching the flask volume of $50 \mathrm{ml}$ and then the reading of absorbance could be performed.

$$
T O G=\frac{\text { TOG reading on the calibration curve }(\mathrm{mg} L-1) x \text { balloon volume }(50 \mathrm{~mL})}{\text { final volume in the beaker }(\mathrm{ml})}
$$

\subsection{Hydrocyclone System}

The hydrocyclone, numerically evaluated in the water/oil separation by Souza (2009), was built with feeding characteristics similar to the aforementioned work, at LABDES in Campina Grande from a PVC billet with the aid of a Centur 30 d CNC lathe Romi.

To study the performance (efficiency) of the hydrocyclone in the separation process, samples with different concentrations of oily water $(100,120,150,200,300,400,500,700,800,1000$ and 2000 mg L-1) were prepared. It is important to note that all concentrations adopted presented a value above the maximum permissible $20 \mathrm{mg}$ L-1 required by CONAMA 2008. Figure 2 shows the oil/water hydrocyclone system (front view), used in the separation process. 
Figure 2. Oil/water hydrocyclone system.

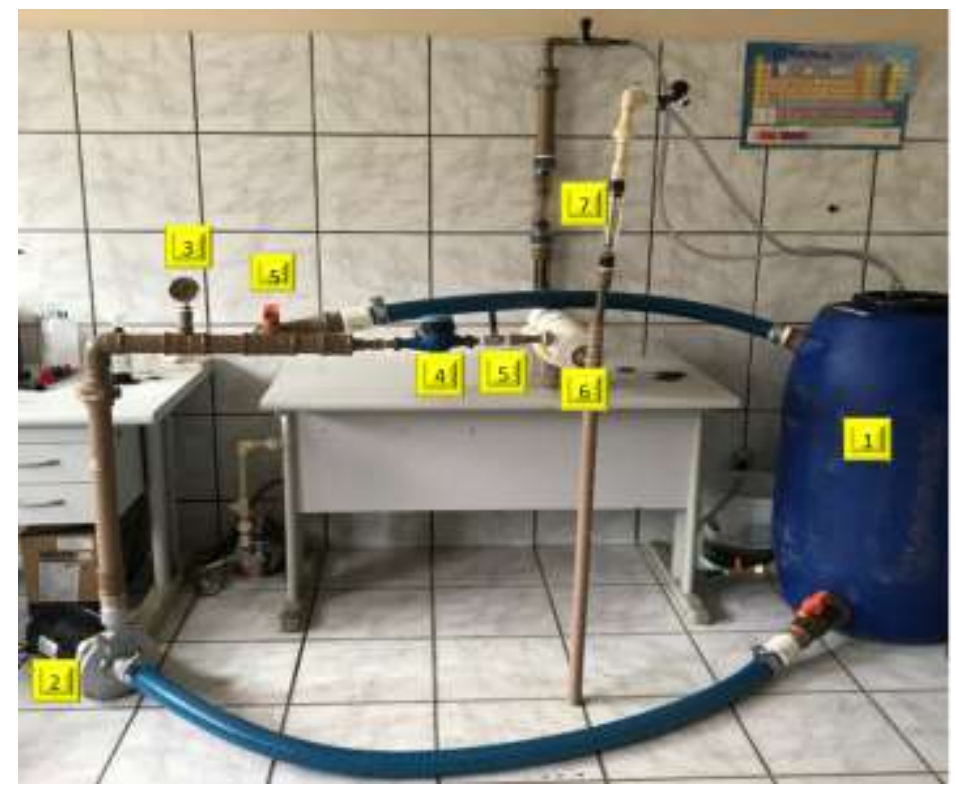

Source: Authors.

1. Feeding tank $(250 \mathrm{~L})$ with continuous agitation;

2. Dancor CAM-W16 T 2 CV three-phase centrifugal pump motor;

3. Glycerin gauge (0-4 bar);

4. Hydrometer;

5. 1/2' ball valves;

6. PVC hydrocyclone (55cm long);

7. Flowmeters (one 0-18LPM and one 0-x LPM).

The total overflow and underflow form the hydrocyclone were measured with the use of flowmeters. Sample collections were carried out in the feed stream, to certify the oil concentration in the feed, and after the overflow and underflow outlets, through the system's ball valves, the respective flows TOG's were determined.

According Alves (2012) efficiency was determined as a function of the concentration of the two streams and their respective flows, based on Equation 2.

$$
E t(\%)=\frac{W_{o f}}{W_{F R}}=\frac{C_{o f} \cdot Q_{o f}}{C_{F e} \cdot Q_{F E}}
$$

where: Et - Total oil removal efficiency (\%); Cof - Overflow concentration (mg L-1); Cfe - Feed concentration (mg L-1); Qof - Overflow flow (L min-1); Qfe - Feed flow rate (L min-1); Wof - Mass flow rate of the overflow (L min-1) and Wfr - Mass flow of the feed (L min-1).

\subsection{Ceramic Membranes}

The microfiltration ceramic membranes were manufactured at LABCEM/UFCG (Ceramic Membrane Laboratory), and tow distinct types were used for the experiments: ceramic membranes MR01-10 and MR01-20, with different porosities, in order to evaluate a greater water production permeated in the treatment of oily water and its removal of oil from the water.

The main materials for the preparation of the membranes were $\alpha$-alumina $\left(\mathrm{Al}_{2} \mathrm{O}_{3}\right)$ provided by the company 
Treibacher Schleifmittel Brasil Ltda, plastic clay, from the city of Boa Vista - PB.

- MR01-10 (Clay and alumina monochannel tubular ceramic membrane). Length: $19.50 \mathrm{~cm}$ and diameter: $2.65 \mathrm{~cm}$.

- MR01-20 (Clay and alumina single channel ceramic tubular membrane) Length: $19.50 \mathrm{~cm}$ and diameter: $2.65 \mathrm{~cm}$.

The microstructures of the MR01-10 and MR01-20 ceramic membranes were analyzed a scanning electron microscope (SEM) in order to observe their characteristics such as: homogeneity, formation of cracks and pores.

After manufacturing and characterizing the membranes, the performance study of the system was carried out only with ceramic microfiltration membranes in two stages. The first consisted in feeding the ceramic membrane system (CMS), shown in Figure 3, with desalinated water, and the second in using oily water to feed the system.

Figure 3. Oil/water separation system membrane.

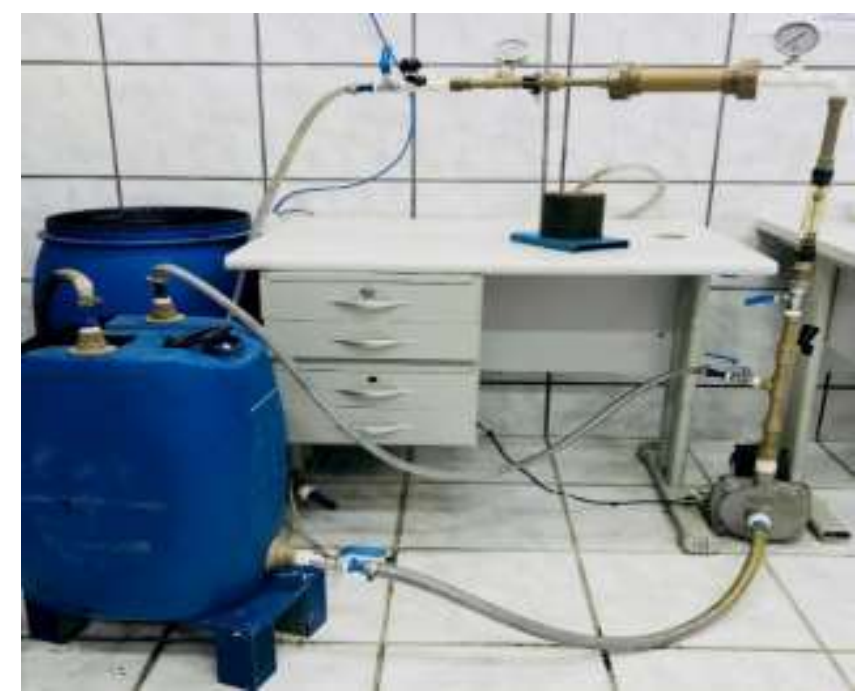

Source: Authors.

The supply with desalinated water was carried out by operating with supply pressures of 1 bar, 2 bar and 3 bar to verify the optimal operating pressure, made possible by manually managing the pressure gauge.

The procedure of each batch carried out in the system consisted of checking the permeate and concentrate flow (end of the membrane length) at intervals of 5 (five) minutes as a function of the system feed pressure, having a total duration of 90 min. With the data obtained, it became possible to verify the optimal operating pressure of the membrane.

The conclusion of the system performance analysis addressed the verification of the permeate and concentrate flow behavior, the batches carried out had the same methodology as the initial step. To verify the removal of oil from the water, a sample was collected at intervals of 30 minutes for measurement of TOG.

\section{Results and Discussion}

\subsection{Efficiency Study - Hydrocyclone system}

The total efficiency of the hydrocyclone was determined by performing a total of 25 batches, varying the feed concentration and the production flow of water from the equipment's underflow outlet, and obtained by applying the data provided in Equation 2. It was observed, by means of the pressure gauge positioned in the system's supply current, that the system's supply pressure remained stable (2.2 bar), even with varying production flows.

Figure 4 graphically presents the efficiencies obtained for the series of experiments carried out, as a function of the concentration of the feed flow (oil/water) to the hydrocyclone system. Five series of experiments were carried out with the 
following concentrations for the feed stream:

Series I: 100, 115, 155, 300 (mg L-1)

Series II: 100, 130, 180, 200, 400 (mg L-1)

Series III: 200, 300, 400, 750, 1800 (mg L-1)

Series IV: 300, 400, 500, 1000, 2000 (mg L-1)

Series V: 350, 650, 800, 1000, 2000 (mg L-1)

Figure 4. Performance analysis of the hydrocyclone system for batch series I, II, III, IV and V.

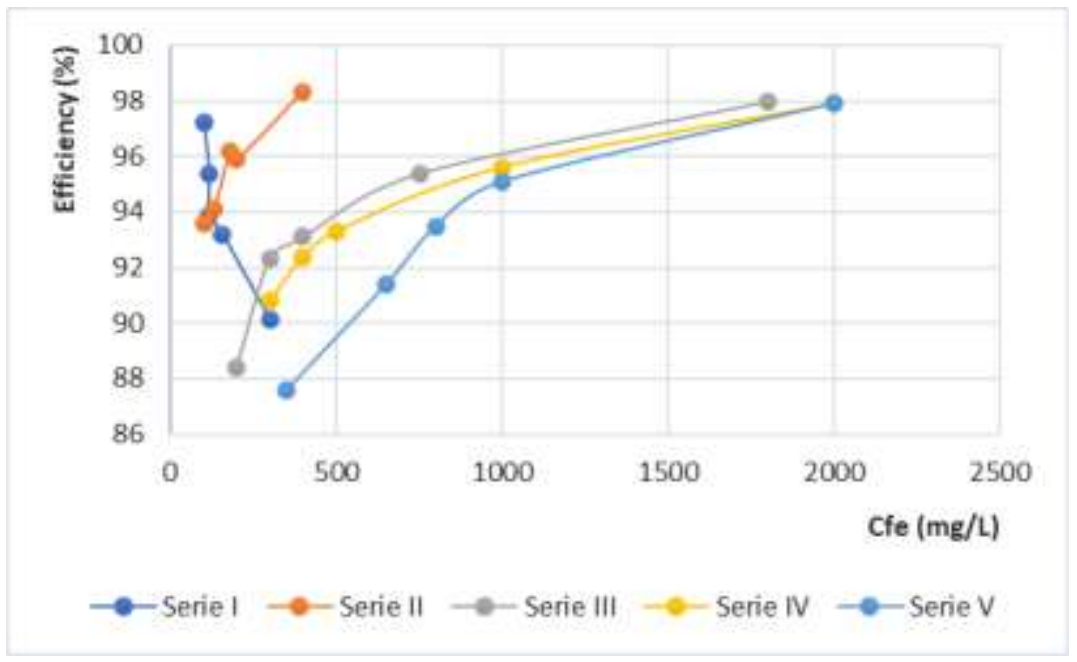

Source: Authors.

It can be seen in Figure 4 that the batches with lower concentration resulted in lower efficiency. This is due to the fact that the decrease in concentration causes an increase in the level of oil dispersion, inducing the formation of an emulsion with smaller particles, which makes the separation process difficult.

In more general terms, for all series considered, the total efficiency values presented values above $86 \%$ and increasing behavior for higher concentrations of the feed mixture in the system, differing only for batches carried out in Series I. Regardless of the concentrations fed, the values obtained for the efficiency of the hydrocyclone were close to each other, and for the study, the efficiency was independent of the concentration of oil present in the aqueous medium, feeding the system.

From the data obtained, the average efficiency for each series was calculated, so that the system operating with different concentration profiles, presented an average efficiency above $90 \%$, significant performance, in terms of oil reduction in the current of the underflow.

In conclusion, even with high concentrations of oil in water, it presented significantly positive results, or even low levels of oil concentrations for feeding the hydrocyclone.

\subsection{Performance of CMs with Desalinated Water}

The characterization of ceramic membranes was performed with desalinated water for twelve membranes type MR0110 and MR01-20, varying the operating pressure, in order to study their best performance from the permeate flow obtained in the system. However, considering that the membranes offer the same morphology pattern, and consequently, they behave similarly, as shown in Figure 5.

For the MR01-10 ceramic membranes, it was observed that the flow versus time behavior for the pressures used was similar. The experiments were carried out until the flow reached the steady state, which was taken as a reference point, 
according to the behavior of Marshall e Daufin (1995), to study the performance of the membrane.

For the cases studied above, it was observed that the pressure of 3 bar was the one with the best flow, where the average flow for the three characterizations performed was determined as a function of the steady state flow value, as shown by the behavior of each experiment, presenting an average value in the order of 430 L (h.m2)-1.

Figure 6 shows the flow curves for type MR01-20 ceramic membranes, for the same operating pressure range given for type MR01-10 membranes.

Figure 5. Variation of permeate flux (Jp) of the ceramic membrane as a function of time (A) Membrane 01 - MR01-10; (B) Membrane 02 - MR01-10 and (C) Membrane 03 - MR01-10.
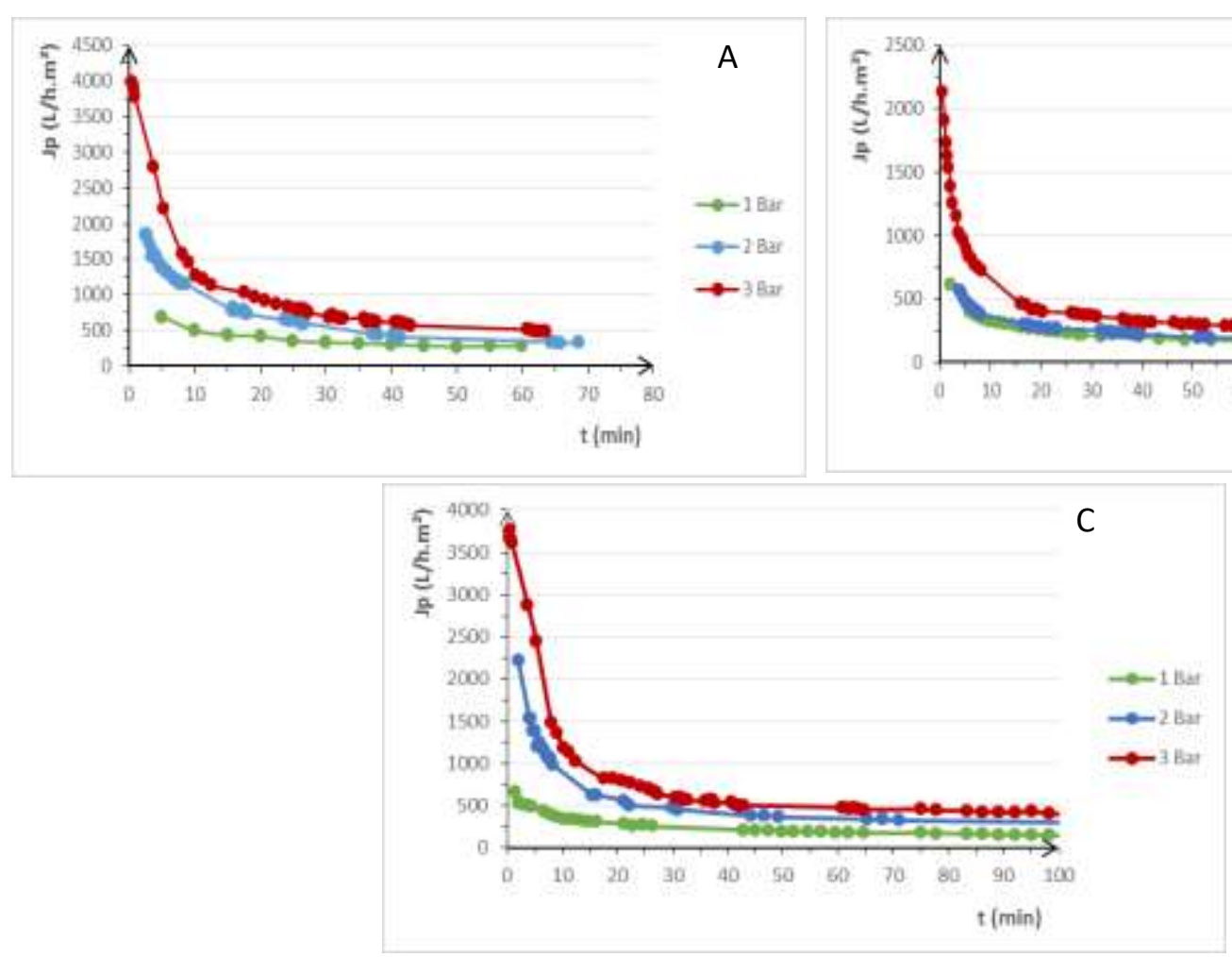

Source: Authors.

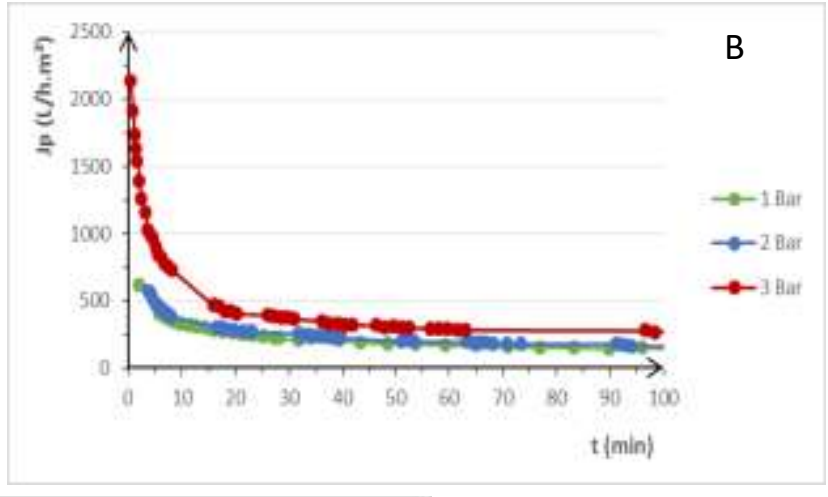

C$$
\text { ( }
$$

As shown for the MR01-10 ceramic membranes in Figure 5, the smallest permeate flux variation from the beginning to the end of the process was observed for an operating pressure of 3 bar, as shown in Figure 6, with the average flow obtained in the order of 1180 L (h.m2)-1. This value was greater than 2.7 times that of the flow obtained with the MR01-10 membrane, which can be explained by the morphology in the membranes used. 
Figure 6. Variation of permeate flux of the ceramic membrane as a function of time (a) Membrane 01 - MR01-20; (b) Membrane 02 - MR01-20 and (c) Membrane 03 - MR01-20.
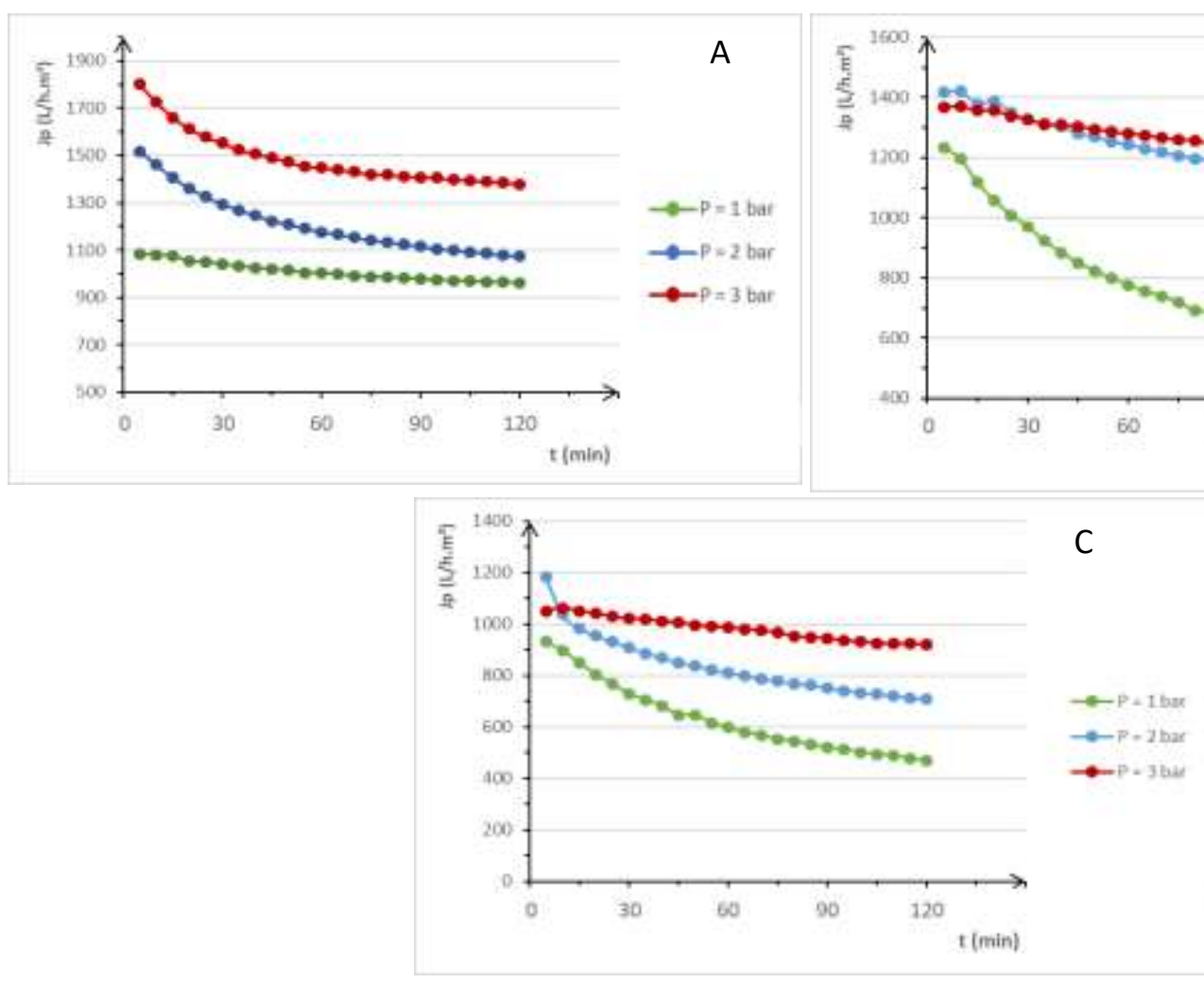

Source: Authors.

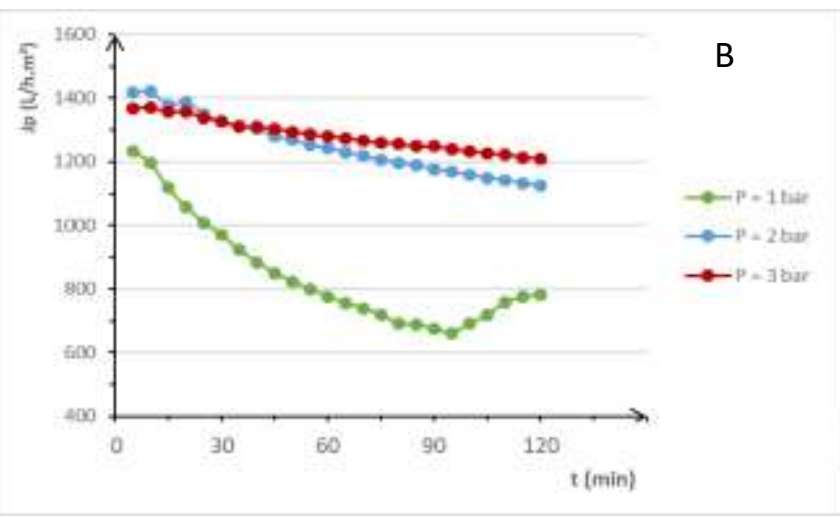

C

\subsection{Morphological Characterization and Porosity}

The ceramic membranes were morphologically characterized by a Scanning Electron Microscope (SEM) in the Laboratory of the Department of Materials Engineering at UFCG. Through this procedure, it was possible to observe that the surfaces of the MR01-10 and MR02-20 ceramic membranes had different morphologies, depending on the concentrations of the ceramic materials used for their production, with the MR01-20 having a pore density higher than the MR01-10.

The study of porosity for the two types of membranes studied was carried out using the Archimedes method (Silva, 2005). Table 1 presents the data obtained during the experiment to analyze the porosity of samples MR01-10 and MR01-20, as well as the average porosity of the respective membranes.

Table 1. Data obtained from samples of MR01-10 and MR01-20 ceramic membranes and calculation of porosity using the Archimedes method.

\begin{tabular}{|c|c|c|c|c|c|}
\hline Membrane & Dry Mass $(G)$ & $\begin{array}{c}\text { Immersed Mass } \\
(G)\end{array}$ & Wet Mass (G) & $P(\%)$ & $\begin{array}{c}\text { Average Porosity } \\
(\%)\end{array}$ \\
\hline MR01-10 - 1 & 13.60 & 9.78 & 16.49 & 43.07 & \multirow{3}{*}{42.79} \\
\hline MR01-10 - 2 & 12.09 & 8.67 & 14.65 & 42.81 & \\
\hline MR01-10 - 3 & 10.52 & 7.53 & 12.73 & 42.50 & \\
\hline MR01-20 - 1 & 10.62 & 7.63 & 13.97 & 52.84 & \multirow{3}{*}{51.98} \\
\hline MR01-20 - 2 & 11.39 & 8.12 & 14.85 & 51.41 & \\
\hline MR01-20 - 3 & 9.52 & 6.80 & 12.43 & 51.69 & \\
\hline
\end{tabular}

Source: Authors. 


\subsection{Performance of MCs with Oily Waters}

In the present study, two samples of water sent by Petrobrás, from the drilling of oil wells at Fazenda Belém - city of Mossoró/RN, were used. Regarding the oil concentration, two different amounts of oil were added to this water, and then called oily water 01 and oily water 02 . The initial oil concentration was approximately $100 \mathrm{mg} \mathrm{L}-1$ and $60 \mathrm{mg} \mathrm{L}-1$ for oily waters 01 and 02 , respectively.

Figure 7 shows the permeate flow behavior for two batches under operating pressure of 3 bar, and different oil concentrations.

Figure 7. Variation of the permeate flux of the ceramic membrane (MR01-20) during its characterization with oily water with a concentration of $100 \mathrm{mg} \mathrm{L}-1$ as a function of time for pressures of 3 bar.

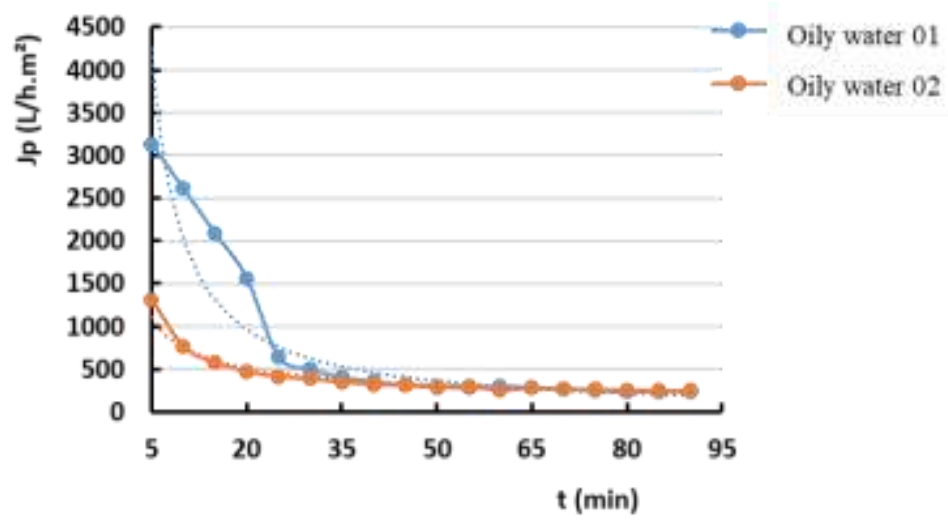

Source: Authors.

It can be seen in Figure 7 that although the samples used generate a distinct initial behavior, up to approximately $45 \mathrm{~min}$, they allowed a stabilization of the permeate flux in the membrane after this time, with values in the range of 240.33 and 249.57 L (h.m2)-1 for oily water 01 and oily water 02 , respectively.

According to resolution number 430/2008 (CONAMA, 2008), the concentration of oil in water to be disposed of in the environment must have a maximum average concentration of $20 \mathrm{mg} \mathrm{L}-1$. Also according to this resolution, the concentration can reach peaks of $35 \mathrm{mg} \mathrm{L}-1$. According to Petrobras, the water to be reinjected in oil production wells must have a maximum of $5 \mathrm{mg} \mathrm{L}-1$ of oil in water, this requirement is due to the fact that the oil droplets present in the water cause a clogging of the pores of the rocks in oil reservoirs causing a drecrease in production. For the two feed concentrations of the study, a removal of $100 \%$ of the oil can be observed, leaving the permeate water within the standard required by the CONAMA resolution of oil concentration.

\section{Conclusion}

The study presented a hydrocyclone system to obtain parameters required by regulatory agencies in water treatment. The hydrocyclone built within the scope of LABDES/UFCG, adapted from Souza (2009), obtained an efficiency above 85\% regardless of the oil concentration in the system supply solution, however for concentrations permissible by CONAMA (2008) it was necessary to implementation of a second treatment, with a ceramic membrane.

The MR01-10 and MR01-20 ceramic membranes produced at LABCEM/UFCG, with porosities of $43 \%$ and 52\%, respectively, presented excellent results in the removal of oil from oily waters, the latter being the one with the highest fluxes under them pressure levels. Consequently, it was chosen to operate as the ceramic membrane system (SMC), as a post- 
treatment to remove the oil remaining in the underflow stream of the hydrocyclone.

From the present study, as suggestions for future work, the study of the behavior of the agreements (axial, tangential and radial), as well as other points, such as operating pressure and temperature of the medium that are intrinsically related to the performance of the hydrocyclone, is important aspect to be addressed. Regarding the use of ceramic membranes in complex systems, it would be interesting to study the investigation of the average permeate production flow, for a given range of oil concentration and sediment density index present in oily water. ceramic membranes depending on the production of permeated water.

\section{References}

Alves, J. V. B. (2012). Hidrociclone para a Separação do Óleo Residual de Água em Refinarias. Dissertação, UFRJ/EQ.

Arruda, A. A. (2008). Otimização de um hidrociclone utilizado na separação de uma mistura líquido-líquido. Dissertação, Programa de Pós Graduação e Processos Ambientais, Universidade Católica de Pernambuco.

Bottino, A., Capannelli, C. \& Del Borghi, A. (2001). Water treatment for drinking purpose: ceramic microfiltration application. Desalination. 141(1), 75-79. https://doi.org/10.1016/S0011-9164(01)00390-3

Castilho, L. R. \& Medronho, R. A. (2000). A Simple procedure for design and performance prediction of Bradley and Rietema hydrocyclones. Minerals Engineering. 13(2), 183 - 191. https://doi.org/10.1016/S0892-6875(99)00164-8

CONAMA (2008). Resolução n 396 de 3 de abril de 2008. Dispões sobre classificação e diretrizes ambientais para o enquadramento das águas subterrâneas e da outras providências. Conselho Nacional de Meio Ambiente. Diário Oficial da União, Brasília, DF, 7 de abril de 2008.

CONAMA (2015) Resolução $n^{\circ} 357$ de 17 de março de 2015*. (RETIFICADA AO FINAL). Dispões sobre classificação e diretrizes ambientais para o enquadramento das águas subterrâneas bem como estabelece as condições e padrões de lançamento de efluentes, e dá outras providências. Conselho Nacional de Meio Ambiente. Diário Oficial da União, Brasília, DF.

Cui, Z., Xing, W., Fan, Y. \& Xu, N. (2011). Pilot study on the ceramic membrane pre-treatment for seawater desalination with reverse osmosis in Tianjin Bohai Bay. Desalination. 279(1-3), 190 - 194. https://doi.org/10.1016/j.desal.2011.06.008

Damasceno L. C. (2009). Tratamento de água oleosas oriundas do processo de produção de óleo de dendê utilizando a flotação por ar dissolvido. Monografia. Unesp - São Paulo.

Ebrahimi, M., Willershausen, D., Ashaghi, K. S., Engel, L., Placido, L., Mund, P., Bolduan, P. \& Czermak, P. (2010). Investigations on the use of different ceramic membranes for efficient oil-field produced water treatment. Desalination. 250 (3), 991-996. https://doi.org/10.1016/j.desal.2009.09.088

Hoffmann, A.C. \& Stein, L.E. (2008). Gas Cyclones and Swirl Tubes - Principles, Design and Operation. Springer - Verlag Berlin Heidelberg. 2ed. https://link.springer.com/book/10.1007/978-3-540-74696-6

Marshall, A. D. \& Daufin, G. (1995). Physico-chemical aspects of membrane foulling by dairy fluids. Foulling and cleaning in pressure driven membrane processes. International Dairy Federation, 1, 8-35.

Matsushita, T., Matsui, Y. \& Shirasaki, N. \& Kato, Y. (2005). Effect of membrane pore size, coagulation time, and coagulant dose on virus removal by a coagulation-ceramic microfiltration hybrid system. Desalination. 178 (1-3), 21-26. https://doi.org/10.1016/j.desal.2004.11.026

Queirós, Y. G. C., Clarisse, M. D., Oliveira, R. S., Reis, R. S., Travalloni, A M. L. \& Lucas, E. F. (2004). Determinação e Correlação do Teor de Óleos e Graxas por Meio de Diferentes Técnicas Espectroscópicas e Gravimétrica. $3^{\circ}$ Congresso Brasileiro de P\&D em Petróleo e Gás. Salvador - BA.

Revista Ciência Hoje (2003). Mistura Indesejável. 32, nº 191.

Salvo, R. V. (2009). Efeitos de Modelos Submalhas no Escoamento em Ciclones. Dissertação. Programa de Graduação Engenharia Mecânica. UFU Uberlândia.

Silva, A. G. P. (2005). Estrutura e propriedades de materiais cerâmicos - Capítulo VII: propriedades físicas - porosidade e densidade de materiais cerâmicos.

Souza Filho, J. E. (2002). Processamento Primário de Fluidos: Separação e Tratamento. Notas de aula - Petrobrás, Salvador.

Souza, J. S. (2009). Estudo Numérico da Termo fluidodinâmica da Separação de Óleos Pesados de uma Corrente de Águas Oleosas via Hidrociclone. Dissertação. Universidade Federal de Campina Grande - PB.

Thomas, J. E. (2001). Fundamentos da engenharia de petróleo. Interciência. (2a ed.). 